\title{
Gawai Dayak sebagai Sumber Sejarah Lokal Tradisi Masyarakat Indonesia Sebelum Mengenal Tulisan
}

\author{
SAIFUL BAHRI \\ bangipoelptk@yahoo.com
}

\begin{abstract}
Abstrak
Penelitian ini bertujuan mengetahui internalisasi tradisi Gawai Dayak sebagai sumber sejarah lokal pada materi tradisi masyarakat Indonesia sebelum mengenal tulisan, di kelas X SMAN 1 Kuala Mandor B, meliputi: (1) penyampaian materi oleh guru,(2)strategi pembelajaran yang digunakan guru, (3)pemahaman siswa terhadap materi. Penelitian ini merupakan penelitian studi kasus. Subjek penelitian 1 guru sejarah dan 9 siswa kelas X. Pengumpulan data dengan observasi langsung, komunikasi langsung, dan dokumentasi. Analisis menggunakan teknik kualitatif model analisis interaktif Miles dan Huberman. Hasil penelitian: (1) penyampaian materi telah dilakukan guru yaitu menyisipkan tradisi Gawai Dayak sebagai sumber sejarah lokal dengan menjelaskan fakta-fakta sejarah mengenai tradisi Gawai Dayak. (2) strategi yang digunakan cenderung mengarah kepada strategi pembelajaran kontekstual yang berhasil meningkatkan minat belajar siswa. (3) pemahaman siswa terlihat dari keterlibatan siswa secara aktif dalam proses pembelajaran seperti tanya jawab, memecahkan masalah yang diberikan guru, menjelaskan dan menganalisis dengan baik, serta berdiskusi dalam kelompok.
\end{abstract}

Kata kunci: tradisi gawai dayak,sumber belajar sejarah

\begin{abstract}
This research aims to know the internalization of Gawai Dayak tradition as a source of local history on the material of the Indonesian tradition before knowing the writing, in class X SMAN 1 Kuala Mandor B, which include: (1) delivery of materials by teachers, (2) learning strategies used by teachers, (3) The students' understanding of the material. This research is a case study. Research subjects consist of 1 history teacher and 9 students of class X. The collection of data was performed by using direct observation, direct communication, and documentation. The data analysis was conducted by utilizing qualitative interactive model of Miles and Huberman. Results of the research are: (1) the delivery of materials have been performed by inserting Gawai Dayak tradition as a source of local history to explain the historical facts about the traditions of Gawai Dayak. (2) the strategies tend to lead to contextual learning strategy that succeed in increasing student interest. (3) the student's understanding can be viewed from the active involvement in the learning process such as frequently asking questions, solving the problem of the teacher, explaining and analyzing them well, as well as performing the group discussion
\end{abstract}

Keywords: Gawai Dayak tradition, history learning resources 


\section{PENDAHULUAN}

Pendidikan merupakan jalan bagi siswa untuk mengembangkan minat dan bakat dalam bidang keilmuan dan sekolah merupakan lembaga yang menyediakan berbagai fasilitas untuk pengembangan potensi dalam diri siswa. Jika seorang anak menjalani proses pendidikan berarti anak tersebut akan mengalami proses belajar. Bukan hanya pendidikan di sekolah tetapi pendidikan di keluarga yang dialami anak sejak lahir, anak akan mengalami proses belajar secara sederhana dan alami dalam keluarga.Dalam buku Educational psychology, Witherington (lewat Aunurrahman, 2010:35), mengemukakan bahwa belajar adalah suatu perubahan di dalam kepribadian yang menyatakan diri sebagai suatu pola baru dari reaksi berupa kecakapan, sikap, kebiasaan, kepribadian atau suatu pengertian. Zuldafrial (2011:5) menjelaskan bahwa belajar pada dasarnya merupakan suatu proses mental karena orang yang belajar perlu memikir, menganalisa, mengingat, dan mengambil kesimpulan dari apa yang dipelajari.

Berdasarkan beberapa pengertian belajar yang dikemukakan oleh para ahli dapat disimpulkan bahwa belajar merupakan perubahan tingkah laku pada diri individu yang terjadi setelah individu melakukan interaksi dengan individu lain maupun dengan lingkungan. Perubahan tingkah laku ditandai dengan adanya proses berpikir dan proses pengambilan kesimpulan hasil interaksi. Sekolah bukan hanya sebagai lembaga yang mendidik dan mengembangkan minat serta bakat siswa tetapi sekolah juga menjadi wadah dalam mewariskan kebudayaan yang terjadi di masa lalu bahkan kebudayaan yang masih berlangsung hingga sekarang perlu untuk disampaikan kepada siswa agar kebudayaan dan tradisi yang ada bisa tetap dilestarikan dan dijaga dengan baik. Pelajaran sejarah sebagai salah satu wadah untuk mewariskan kebudayaan tersebut bukan hanya sejarah nasional yang perlu disampaikan tetapi juga sejarah lokal yang ada di daerah juga perlu disampaikan kepada siswa.

Pada bukunya Pengantar Umum Pendidikan, Suwarno (lewat Hasbullah, 2009:50-51) menjelaskan fungsi sekolah yang salah satunya sebagai konservasi dan transmisi kultural yaitu memelihara warisan budaya yang hidup dalam masyarakat dengan jalan menyampaikan warisan kebudayaan tadi (transmisi kultural) kepada generasi muda, dalam hal ini tentunya adalah anak didik.

Hariyono (1995:1) menjelaskanpengertiansejarah yaitu pengalaman kelompok manusia. Jika sejarah dilupakan atau diabaikan, kita sebenarnya berhenti menjadi manusia. Tanpa sejarah, manusia tidak mempunyai pengetahuan tentang dirinya, terutama dalam proses ada dan mengada. Manusia yang demikian tidak mempunyai memori atau ingatan, sehingga pada dirinya dituntut suatu tanggungjawab. Kedudukan sejarah yang sangat penting sehingga menjadi mata pelajaran yang wajib dipelajari setiap siswa di sekolah, dengan mempelajari sejarah siswa akan mampu menggali berbagai kejadian dan peristiwa masa lalu yang sangat penting. Untuk itu dituntut peran guru dalam menciptakan proses pembelajaran sejarah yang aktif, nyaman, dan tidak membosankan bagi siswa.Guru dapat memanfaatkan lingkungan sekitar siswa sebagai sumber belajar bagi siswa, banyaknya tradisi sejarah lokal yang dapat dimanfaatkan guru dalam proses pembelajaran dan dihubungkan dengan materi-materi pelajaran sejarah yang memang memiliki keterkaitan. Namun perlu diingat bukan berarti guru mengabaikan materi maupun contoh yang telah ada di bukubuku paket tetapi guru dituntut harus lebih mampu memanfaatkan situasi di lingkungan sekitar siswa sebagai sumber belajar. Guruguru yang mengajar di daerah yang sangat jauh dari museum dapat menjadikan sejarah lokal sebagai satu strategi dalam menyampaikan pelajaran sejarah, dengan demikian guru dapat melatih siswa untuk melihat adanya sejarah lokal sebagai suatu kenyataan yang terjadi dan masih berlangsung di sekitar kehidupan siswa hingga sekarang.

Indonesia kaya akan tradisi sejarah, kaya akan peninggalan-peninggalan sejarah dan terdapat bermacam-macam suku yang ada di Indonesia. Dengan keadaan seperti ini guru dapat melakukan pembelajaran sejarah 
secara efektif dengan menghubungkan sejarah-sejarah lokal yang ada di sekitar siswa dengan materi pelajaran sejarah yang sedang dibahas.

Kalimantan Barat memiliki banyak tradisi budaya yang dapat dikaitkan dengan materi pelajaran sejarah.Salah satu contoh adalahtradisi Gawai Dayak yang sampai sekarang masih dilaksanakan oleh masyarakat suku dayak, dapat dikaitkan dengan materi tradisi masyarakat Indonesia sebelum mengenal tulisan.Daerah Kapuas Hulu memiliki berbagai macam sub suku Dayak, salah satunya adalah suku Dayak Taman. Wulandari (2010:85) menjelaskan pada dasarnya pelaksanaan Gawai pada suku Dayak Taman merupakan wujud penghormatan kepada leluhur, termasuk orang tua dan sanak keluarga yang sudah meninggal dunia. Setiap orang taman cenderung menganggap Gawai sebagai kewajiban adat yang harus dilaksanakan. Pada konsep keyakinan orang Taman ketentraman, kedamaian, kesejahteraan dan kemakmuran dalam hidup seseorang hanya bisa diperoleh apabila orang tersebut mampu menghargai dan menghormati sang pencipta serta menjaga keserasian hubungannya dengan alam, para leluhur dan segala macam makhluk ciptaan Tuhan.

Berdasarkan kegiatan pra observasi yang telah dilakukan di Sekolah Menengah Atas Negeri 1 Kuala Mandor Bdiketahui bahwa, guru mata pelajaran sejarah yang ada di sekolah tersebut telah menyampaikan materi sejarah lokal, namun penyampaian ini dilakukan pada materi-materi tertentu saja, misalnya materi yang memang bisa dihubungkan dengan sejarah lokal. Selain itu penyampaian materi hanya berdasarkan pengetahuan yang dimiliki guru saja. Metode pengajaran yang digunakan guru masih dominan menggunakan metode ceramah sehingga dikhawatirkan akan dapat menimbulkan kebosanan pada siswa. Hal ini dapat dicegah dengan menimbulkan rasa ingin tahu siswa terhadap sejarah yaitu dengan cara guru tersebut mau menerangkan secara mendalam dan terperinci mengenai sejarah-sejarah lokal yang ada di sekitar siswa dan mendiskusikannya secara bersama-sama serta membandingkan materi yang ada di buku pelajaran dengan kejadian nyata yang terjadi di sekitar kehidupan siswa seperti tradisi Gawai Dayak yang memang dilaksanakan setiap tahun oleh masyarakat suku Dayak.

Dengan pembelajaran seperti ini diharapkan siswa dapat memiliki ketertarikan belajar sejarah dan memiliki rasa ingin tahu lebih banyak lagi mengenai sejarah-sejarah lokal yang ada.Upacara tradisi Gawai Dayak merupakan salah satu upacara tradisi yang sampai sekarang masih terus aktif dilakukan oleh masyarakat suku Dayak. Upacara tradisi Gawai Dayak juga merupakan salah satu sumber sejarah lokal yang ada di KualaMandor B dan sangat perlu sekali untuk disampaikan dan dijelaskan kepada siswa. Pada materi tradisi masyarakat Indonesia sebelum mengenal tulisan, dapat dijelaskan mengenai tradisi Gawai Dayak sebagai tradisi yang sudah berlangsung sangat lama dan masih terus dipertahankan hingga saat ini dan tradisi ini merupakan sejarah lokal yang terdapat di daerah Kalimantan Barat umumnya dan daerah Kapuas Hulu khususnya tradisi Gawai Dayak Taman.

Fokus penelitian secara umum dalam penelitian ini adalah bagaimanakah Internalisasi tradisi Gawai Dayak di Putussibau sebagai sumber sejarah lokal pada materi tradisi masyarakat Indonesia sebelum mengenal tulisan pada kelas X Sekolah Menengah Atas Negeri 1 Kuala Mandor B Pontianak?. Fokus penelitian ini secara khusus adalah: (1)Bagaimanakah penyampaian materi tradisi masyarakat Indonesia sebelum mengenal tulisan oleh guru kepada siswa kelas $\mathrm{X}$ Sekolah Menengah Atas Negeri 1 Kuala Mandor B Pontianak?, (2)Bagaimanakah strategi guru dalam internalisasi tradisi Gawai Dayak di Sekolah Menengah Atas Negeri 1 Kuala Mandor B sebagai sumber sejarah lokal pada materi tradisi masyarakat Indonesia sebelum mengenal tulisan di kelas X Sekolah Menengah Atas Negeri 1 Kuala Mandor B?, (3) Bagaimanakah pemahaman siswa terhadap tradisi Gawai Dayak di Putussibau sebagai sumber sejarah lokal pada materi tradisi masyarakat Indonesia sebelum mengenal tulisan di kelas X Sekolah Menengah Atas Neg- 
eri 1 Kuala Mandor B?

\section{METODE}

Penelitian ini menggunakan metode deskriptif dengan bentuk penelitian studi kasus. Subjek dalam penelitian adalah 1 orang guru sejarah dan 9 orang Siswa kelas X (yang meliputi 3 orang siswa kelas $\mathrm{X}-1,3$ orang siswa kelas X-3, dan 2 orang siswa kelas X-3) Sekolah Menengah Atas Negeri 1 Kuala Mandor B. Dalam penentuan subjek digunakan teknik wawancara dan observasi langsung berperan pasif, untuk memperoleh data dan informasi mengenai internalisasi tradisi Gawai Dayak di Kuala Mandor B dalam materi pembelajaran tradisi masyarakat Indonesia sebelum mengenal tulisan pada siswa kelas $\mathrm{X}$ Sekolah Menengah Atas Negeri 1 Kuala Mandor B.

Teknik pengumpulan data merupakan langkah yang paling strategis dalam penelitian, karena utama dari penelitian adalah mendapatkan data. Tanpa mengetahui teknik pengumpulan data, maka peneliti tidak akan mendapatkan data yang memenuhi standar data yang ditetapkan. Secara umum terdapat empat macam teknik pengumpulan data, yaitu observasi, wawancara, dokumentasi, dan gabungan atau triangulasi(Sugiyono, 2010:62-63). Teknik pengumpulan data yang digunakan dalam penelitian ini adalah:Observasilangsung, komunikasilangsung, dan studidokumenter,

Teknik analisis data yang digunakan dalam penelitian ini adalah teknik analisis data kualitatif model analisis interaktif, mengikuti model Miles and Huberman. Miles and Huberman (lewat Sugiyono, 2010:91), mengemukakan bahwa aktivitas dalam analisis data kualitatif dilakukan secara terus menerus sampai tuntas, sehingga datanya sudah jenuh. Aktivitas dalam analisis data, yaitu data reduction, data display, dan conclusion drawing/verification.

\section{HASIL DAN PEMBAHASAN}

Pelaksanaan pembelajaran sejarah yang ada di Sekolah Menengah Atas Negeri 1 Kuala Mandor B diadakan pada setiap kelas, mulai dari kelas X sampai kelas XII di semua jurusan, baik jurusan IPA maupun IPS. Pada semua kelas pelajaran sejarah diajarkan selama 2 jam pelajaran dalam satu minggu. Kegiatan kurikuler dikelompokkan menjadi intrakurikuler dan ektrakurikuler. Kegiatan intrakurikuler merupakan kegiatan pembelajaran untuk menguasai kompetensi, dengan alokasi waktu atau jam belajar yang dimulai dari pukul 07.00 s.d pukul 13.00 WIB selama 6 hari kerja. Pembagian jam pelajaran sejarah ini sesuai dengan kerangka dasar dan struktur kurikulum dalam Kurikulum Tingkat Satuan Pendidikan (KTSP).Pada proses pembelajaran sejarah, Jariyanti guru sejarah kelas X Sekolah Menengah Atas Negeri 1 Kuala Mandor B (wawancara 27 September 2012), mengatakan bahwa:

Sebelum melaksanakan proses pembelajaran di kelas, saya terlebih dahulu menyiapkan Rencana Pelaksanaan Pembelajaran yang berkaitan dengan materi yang akan saya jelaskan dan saya juga mempersiapakan silabus. Selain itu saya juga terlebih dahulu mempelajari bahan atau materi yang akan saya ajarkan dan menyiapakan buku yang akan digunakan sebagai sumber belajar.

Joshua Aryananda (27 September 2012) juga mengatakan "guru mengajarkan pelajaran sejarah adalah dengan menyampaikan dan menjelaskan materi pelajaran sejarah, kadang-kadang guru juga memberikan contoh tentang peristiwa yang pernah terjadi di Kuala Mandor B seperti upacara-upacara adat yang ada di putussibau, misalnya seperti Gawai Dayak". Sebastianus Reczy. S (wawancara, 27 September 2012) mengatakan "tradisi Gawai Dayak merupakan cara masyarakat di masa lampau dalam mengucapkan rasa syukur kepada tuhan yang maha esa dan nilai-nilai yang dapat saya petik adalah penting sekali bagi kita untuk selalu mengucapkan rasa syukur atas apa yang telah tuhan berikan".Mochamad Djusanudin (wawancara, 18 September 2012), sebagai kepala sekolah mengatakan:

Saya sangat mendukung guru untuk menyampaikan menyampaikan materi yang berkaitan dengan sejarah lokal, karena penting untuk diketahui siswa, sejarah lokal dapat melatih siswa untuk untuk mening- 
katkan kesadaran sejarah, membangkitkan rasa kebanggaan terhadap sejarah dan menghargai atas apa yang telah dimilikinya, sehingga dapat timbul rasa tanggungjawab untuk melestarikannya. Apalagi Gawai Dayak merupakan tradisi asli masyarakat Kalimantan memang perlu dilestarikan dengan cara memperkenalkan kepada peserta didik.

Pemahaman siswa terhadap materi yang disampaikan oleh guru merupakan hal yang sangat penting, siswa yang paham akan dapat menyerap materi yang diajarkan guru dengan baik, sebaliknya siswa yang kurang paham tidak akan mendapatkan apa-apa dari materi yang dijelaskan guru selain kebingungan, untuk itu guru harus dapat mengetahui sejauh mana siswa mengerti akan materi yang telah disampaikan.

Pembelajaran sejarah di Sekolah Menengah Atas Negeri 1 Kuala Mandor B berlangsung selama 2 jam mata pelajaran dalam seminggu. Khusus untuk kelas $\mathrm{X}$ pelajaran sejarah diajarkan dua kali dalam seminggu, satu kali pertemuan dengan durasi waktu 1 jam pelajaran atau 45 menit.Terkait dengan penyampaian materi oleh guru sejarah, dari hasil observasi maupun hasil wawancara (observasi dan wawancara, 19, 26 dan 27 September 2012) yang dilakukan kepada siswa maupun guru, guru telah menyampaikan materi tradisi masyarakat Indonesia sebelum mengenal tulisan dengan optimal. Dapat dikatakan demikian karena dalam menyampaikan materi karena guru mampu menguasai bahan ajar yang disampaikannya, pada saat mengajar guru juga mampu mengendalikan situasi kelas dan dengan sabar guru menjelaskan materi sampai siswa mengerti meskipun penjelasan yang sama terus dijelaskannya secara berulang-ulang di 3 kelas yang berbeda, tidak hanya itu, guru juga tidak hanya sekedar menyampaikan materi pelajaran sejarah tetapi dengan menyampaikan tradisi lokal yang terdapat di sekitar siswa guru berusaha menyadarkan siswa bahwa pentingnya menjaga dan melestarikan tradisi lokal, mendidik siswa untuk mempunyai sikap saling menghormati akan berbagai macam perbedaan yang dimiliki bangsa Indonesia serta menumbuhkan rasa tanggungjawab dan rasa kebanggaan atas sejarah panjang yang dimiliki oleh bangsa Indonesia. Namun pada proses penyampaian materi pelajaran sejarah guru masih dominan dalam menggunakan metode ceramah kepada siswa.

Kemp (lewat Sanjaya, 2011:126) menjelaskan strategi pembelajaran sejarah adalah suatu kegiatan pembelajaran yang harus dikerjakan guru dan siswa agar tujuan pembelajaran dapat dicapai secara efektif dan efisien. Dick dan Carey (lewat Sanjaya, 2011:126) juga menyebutkan bahwa strategi pembelajaran adalah suatu set materi dan prosedur pembelajaran yang digunakan secara bersama-sama untuk menimbulkan hasil belajar pada siswa. Untuk mencapai tujuan dari pembelajaran maka diperlukan strategi pembelajaran, yang termasuk dalam strategi pembelajaran adalah penggunaan metode belajar yang tepat dan sesuai dengan materi, persiapan Rencana Pelaksanaan Pembelajaran, menggunakan model pendekatan pembelajaran yang tepat, serta pemilihan bahan-bahan ajar yang sesuai yang dapat membangkitkan gairah belajar siswa.

Daldjoeni (1997:79) mengemukakan bahwa fungsi dari pembelajaran sejarah adalah sejarah menyajikan berbagai pelajaran dari masa lampau dan ini dapat dimanfaatkan untuk masa sekarang. Kita dapat bercermin banyak dari masa lampau kita baik mengenai keberhasilan maupun kegagalan kita, karena itulah sejarah sangat penting untuk dipelajari oleh setiap orang. Guru harus mampu menyajikan pembelajaran yang dapat menarik minat siswa untuk belajar sejarah. Guru dapat bersama-sama mengajak siswa untuk membuat kesimpulan dari apa yang telah mereka pelajari dalam pelajaran sejarah, dengan mendengarkan kesimpulan yang dikemukakan siswa guru akan mengetahui apa yang ada dipikiran siswa mengenai apa yang telah dipelajarinya. Cara penyampaian materi maupun strategi yang digunakan oleh guru sangat berpengaruh terhadap pemahaman siswa. Guru harus lebih memperhatikan lagi terkait cara penyampaian dan strategi yang digunakan. Penyampaian materi yang baik dapat membantu siswa untuk memahami pelajaran sejarah. 


\section{SIMPULAN}

Guru memiliki peranan penting dalam proses pembelajaran, cara guru menyampaikan materi pembelajaran sangat berpengaruh dalam meningkatkan minat belajar pada diri siswa, guru harus mampu menciptakan suasana belajar yang kondusif dan tidak cenderung membosankan. Untuk mencegah rasa bosan pada diri siswa guru dapat menyisipkan peristiwa-peristiwa sejarah yang terjadi di sekitar siswa ke dalam materi pelajaran sejarah yang relevan, sehinggan strategi seperti ini diharapkan dapat membangkitkan minat siswa untuk belajar sejarah dan mengasah pemahaman siswa tentang sejarah lokal yang ada di sekitarnya. Mulyana dan Gunawan (2007:6) mengemukakan bahwa mulai dari lingkungankeluarga siswa tinggal hingga lingkungan masyarakatnya yang lebih luas, dapat menjadi sumber belajar bagi pembelajaran sejarah lokal. Pembelajaran sejarah lokal di sekolah dapat dimulai dari lingkungan terdekat siswa hingga lingkungan yang lebih jauh. Hal yang terpenting adalah bagaimana siswa diberikan pemahaman konsep-konsepdari sejarah, yang dapat dijadikan alat analisa oleh siswa dalam melihat realitas masyarakat yang senantiasa mengalami perubahan.

Berdasarkanpengolahan data yang telahdisajikan, makasecaraumumdapatditarikkesimpulaninternalisasi tradisi Gawai Dayak sebagai sumber sejarah lokal pada materi tradisi masyarakat Indonesia sebelum mengenal tulisan telah diterapkan oleh guru dan mendapat respon yang baik dari siswa, hal ini dapat dilihat dari proses pembelajaran di mana siswa terlibat secara aktif saat guru melakukan tanya jawab.

Secara khusus dapat ditarik kesimpulan sebagai berikut: (1)Penyampaian materi tradisi masyarakat indonesia sebelum mengenal tulisan telah dilakukan guru dengan optimal, berdasatkan hasil observasi dan wawancara yang yang telah dilakukan peneliti di kelas XSekolah Menengah Atas Negeri 1 Kuala Mandor B, di mana guru tidak hanya sekedar menyampaikan materi pelajaran sejarah, namun juga menghubungkannya dengan sejarah lokal yang terdapat di sekitar siswa, seperti Gawai Dayak yang merupakan sejarah lokal di Kuala Mandor B, sehingga berhasil membawa siswa untuk terlibat aktif dalam kegiatan pembelajaran sejarah.(2) Strategi guru dalam internalisasi tradisi Gawai Dayak di Kuala Mandor B sebagai sumber sejarah lokal pada materi tradisi masyarakat indonesia sebelum mengenal tulisan, dilaksanakan dengan menjelaskan fakta-fakta sejarah yang dekat dengn kehidupan di sekitar siswa. Strategi ini berhasil meningkatkan minat siswa untuk belajar materi ini, terlihat dari banyaknya siswa yang antusias dalam bertanya, menjawab, maupun mengeluarkan pendapatnya. Strategi yang digunakan guru cenderung mengarah kepada pembelajaran kontekstual (3)Pemahaman siswa terhadap tradisi Gawai Dayak di Kuala Mandor B sebagai sumber sejarah lokal pada materi tradisi masyarakat Indonesia sebelum mengenal tulisan, terlihat dari keterlibatan siswa secara aktif dalam proses pembelajaran. Siswa yang tumbuh minat belajar sejarahnya akan terlibat dalam pembelajaran sejarah, seperti tanya jawab memecahkan masalah, diskusi, menjelaskan, menganalisis dan mengerjakan tugas-tugas yang diberikan oleh guru.

\section{UCAPAN TERIMA KASIH}

Dalam kesempatan ini penulis mengucapkan terima kasih kepada berbagai pihak yang telah membantu dalam pelaksanaan penelitian ini khususnya SMAN 1 Kuala Mandor B. Penulis juga mengucapkan terima kasih kepada dewan redaksi Jurnal Socia atas kesempatan yang diberikan sehingga paper ini dapat diterbitkan pada Jurnal Socia edisi September 2015.

\section{DAFTAR PUSTAKA}

Aunurrahman. 2010. Belajar dan Pembelajaran. Bandung: Alfabeta.

Daldjoeni. 1997. Dasar-dasar Ilmu Pengetahuan Sosial untuk Mahasiswa IKIP (FKIP) dan Guru Sekolah Lanjutan. Bandung: Alumni.

Hariyono. 1995. Mempelajari Sejarah Secara Efektif. Jakarta: Pustaka Jaya

Hasbullah. 2009. Dasar-dasar Ilmu Pendidikan. Jakarta: Raja Grafindo Persada.

Mulyana, A. dan Gunawan, R. 2007. Sejarah 
Lokal Penulisan dan Pembelajaran di Sekolah. Bandung: Salamina Press.

Sanjaya, W. 2011. Strategi Pembelajaran Berorientasi Standar Proses Pendidikan. Jakarta: Kencana Prenada Media.

Sugiyono. 2010. Memahami Penelitian Kualitatif. Bandung: Alfabeta.
Wulandari, B. J. W. 2010. Pesona Malapi dalam Bingkai Warisan Budaya Taman di Kabupaten Kapuas Hulu. Pontianak: Balai Pelestarian Sejarah dan Nilai Tradisional Pontianak.

Zuldafrial. 2011. Strategi Belajar Mengajar. Pontianak: STAIN Pontianak Press. 